\title{
EXPRESSION OF MURINE CORONAVIRUS GENES 1 AND 7 IS SUFFICIENT FOR VIRAL RNA SYNTHESIS
}

\author{
Kyongmin Hwang Kim and Shinji Makino \\ Department of Microbiology \\ The University of Texas at Austin \\ Austin, Texas
}

\section{INTRODUCTION}

The genome of mouse hepatitis virus (MHV) is known to contain eight or nine genes that are encoded by mRNAs 1, 2, 2-1, 3, 4, 5 (for both 5a and 5b), 6 and 7. The gene 2, 2-1, 4 and 5 a products are not essential for MHV replication at least in tissue culture ${ }^{1-3}$. The 5'-most MHV gene, gene 1 most probably encodes virus RNA polymerase and proteases, the activities that are necessary for MHV RNA synthesis ${ }^{4}$. Gene 3 encodes S protein which is responsible for binding to cellular receptor ${ }^{5}$ and for induction of cell fusion ${ }^{6}$. MHV $5 \mathrm{~b}$ protein is present as a virus structural protein ${ }^{7}$. Gene 6 encodes $\mathrm{M}$ protein which is believed to be essential for virus assembly. The most $3^{\prime}$ region of the MHV genome, gene 7, encodes the $\mathrm{N}$ protein. $\mathrm{N}$ protein binds to MHV genomic RNA forming a helical nucleocapsid. Anti-N antibody inhibits MHV RNA replication in vitro $^{8}$, indicating that $\mathrm{N}$ protein is necessary for MHV RNA replication. Whether the remaining proteins, $\mathrm{S}, \mathrm{ns} 5 \mathrm{~b}$ and $\mathrm{M}$ are necessary for MHV RNA is not known.

An MHV-JHM defective-interfering (DI) RNA, DIssA, which is nearly genomic in size ${ }^{9}$, replicates by itself in the absence of helper virus infection ${ }^{10}$ and is efficiently packaged into MHV particles ${ }^{9,11}$. Almost all MHV mRNA synthesis is strongly inhibited in DIssA-replicating cells, whereas synthesis of mRNA 7 and its product $\mathrm{N}$ protein is not inhibited ${ }^{9}$. Oligonucleotide T1 fingerprinting analysis of DIssA suggested that gene 1 and gene 7 of DIssA are essentially intact, whereas multiple deletions are present from genes 2 to $6^{9}$.

In the present study, we examined possibilities that mRNA 7 is synthesized form DIssA template RNA, but not from helper virus template RNA, and that the gene 1 products and $\mathrm{N}$ protein are sufficient for the MHV RNA synthesis. Our study demonstrated that these possibilities are, in fact, the case. 


\section{MATERIALS AND METHODS}

\section{Viruses and Cells}

The MHV-A59 temperature-sensitive mutant, LA $16^{12}$, the plaque-cloned MHV$\mathrm{JHM}$, and virus sample obtained after 19 undiluted passage of original plaque-cloned MHV-JHM (JHM19th) ${ }^{9}$ were used. Mouse DBT cells were used for RNA transfection and propagation of viruses.

\section{Radiolabeling of Viral RNAs and Agarose Gel Electrophoresis}

Virus-specific RNAs in virus-infected cells were labeled with ${ }^{32} \mathrm{Pi}$ as previously described ${ }^{13}$ and separated by electrophoresis on $1 \%$ urea-agarose gels as described previously 9 .

\section{Preparation of Virus-Specific Intracellular RNA and Northern Blotting}

Virus-specific RNAs were extracted from virus-infected cells ${ }^{13}$. For each sample, $1.5 \mu \mathrm{g}$ of intracellular RNA was denatured and electrophoresed through a $1 \%$ agarose gel containing formaldehyde, and the separated RNA was blotted onto nylon filters ${ }^{14}$. The RNA on the filters was hybridized with ${ }^{32} \mathrm{P}$-labeled probes specific for the various region of MHV RNA ${ }^{14}$.

\section{Isolation of Clones Containing DIssA-Specific Sequence}

For the amplification of a DIssA-related subgenomic RNA, cDNA was first synthesized from intracellular RNA as previously described ${ }^{15}$, using as a primer oligonucleotide 1116 (5'-CTGAAACTCTTTTCCCT-3'), which binds to positive-strand MHV mRNA 7 at nucleotides 250 to 267 from the $5^{\prime}$-end of mRNA 7. MHV-specific cDNA was then incubated with oligonucleotide $78^{15}$, which binds to antileader sequence of MHV RNA, in PCR buffer as described previously ${ }^{15}$. DIssA subgenomic RNA-specific reverse transcriptase (RT)-PCR products were examined by Southern blot analysis in which RT-PCR products were separated by agarose gel electrophoresis and hybridized with a probe which corresponds to 1.5 to 1.7 $\mathrm{kb}$ from the 3'-end of MHV genomic RNA. The identified $1.2 \mathrm{~kb}$-long DIssA subgenomic RNA-specific RT-PCR product was eluted from the preparative gel and cloned into TA cloning vector (Invitrogen). Clones containing DIssA-specific sequence were isolated by colony hybridization using the same probe which was used for Southern blot analysis.

\section{RESULTS}

\section{Strategy for Analysis of DIssA-Related RNAs}

We wanted to determine whether mRNA 7 detected in DIssA RNA-replicating cells was derived from the DIssA template or from helper virus genomic template. We established experimental conditions so that DIssA-derived RNA, but not helper virus-derived RNA, was efficiently synthesized. Two parental viruses were used: JHM19th and LA16, which is an MHV-A59 temperature sensitive mutant with an RNA phenotype. In JHM19th-infected cells DIssA, mRNA 7 and the $2.2 \mathrm{~kb}$-long DIssE ${ }^{9}$ are synthesized, whereas synthesis of the helper virus-derived mRNAs is strongly inhibited at nonpermissive temperature ${ }^{9}$. DBT cells were infected with either JHM19th or LA16 alone, or were coinfected with both virus samples and cultured at $32.5^{\circ} \mathrm{C}$, which is the permissive temperature for LA16. After overnight 
Figure 1. Urea-agarose gel electrophoresis of MHV-specific intracellular RNA species. DBT cells were infected with JHM19th (lane 1), P3 virus sample from JHM19th and LA 16-coinfected cells (lane 2), and LA 16 (lanes 3 and 4). Viruses were grown at $39.5^{\circ} \mathrm{C}$ (lanes $1-3$ ) or $32.5^{\circ} \mathrm{C}$ (lane 4) and virus-specific RNA was labeled with ${ }^{32} \mathrm{Pi}$ in the presence of actinomycin D. Extracted RNA was electrophoresed on a $1 \%$ urea-agarose gel. The three minor bands marked with asterisks (lane 2) were newly synthesized DI RNA species generated during virus passage.

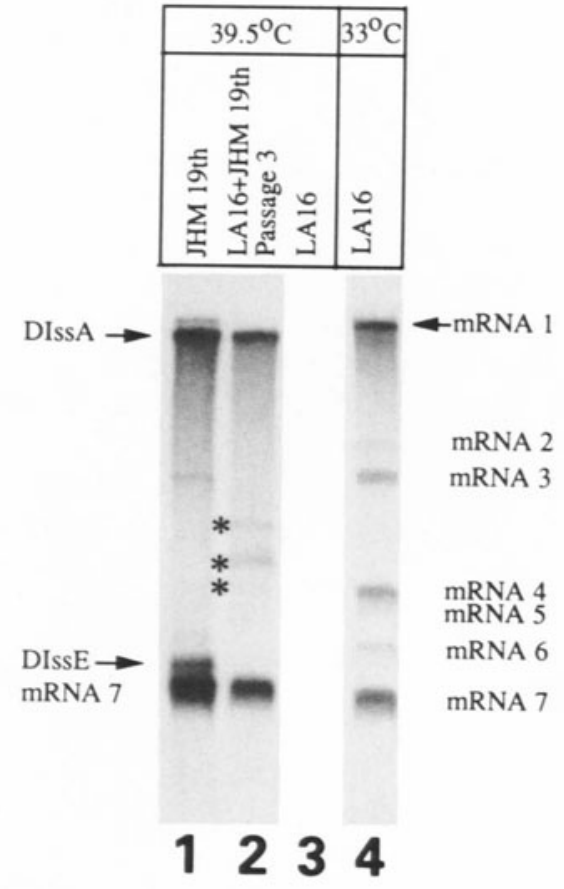

incubation, culture fluid was collected and virus samples were named passage $0(\mathrm{P} 0)$ samples and these virus samples were further passaged on DBT cells several times at the permissive temperature. Because MHV-A59 usually grows about 10 times better than MHV-JHM, we expected that LA16 would grow better than MHV-JHM in coinfected cells and that during passage, MHV-JHM would be eliminated from the virus samples.

We examined MHV-specific intracellular RNA species of these passaged virus sample at the nonpermissive temperature. Infected cells were cultured at $39.5^{\circ} \mathrm{C}$ or $32.5^{\circ} \mathrm{C}$, and virus-specific RNAs were labeled with ${ }^{32} \mathrm{Pi}$ in the presence of actinomycin D. Extracted intracellular virus-specific RNA was electrophoresed on a 1\% urea-agarose gel (Fig. 1). Synthesis of DIssA and mRNA 7 was clearly apparent in the cells infected with the P3 sample from coinfected cells, whereas synthesis of helper virus mRNAs and DIssE RNA was not detected (Fig. 1, lane 2). In addition to DIssA and mRNA 7, other minor MHV-specific RNA species were also detected (Fig. 1, lane 2 asterisks); these bands were most likely newly generated DI RNAs. Helper virus-derived mRNAs, 1 through 6, were not evident at the nonpermissive temperature in the cells infected with the P3 sample from JHM19th and LA 16-coinfected cells, therefore, the mRNA 7 shown in Fig. 1 lane 2 was most likely derived from the DIssA template RNA.

We studied the structure of the mRNA 7 by RNase $T_{1} 1-\mathrm{D}$ oligonucleotide fingerprinting. The mRNA 7 fingerprint patterns from P1 and P3 samples of co-infected cells were very similar to that of JHM, but not to LA16 (data not shown). This data clearly demonstrated that mRNA 7 was indeed synthesized from the MHV-JHM-derived DIssA template RNA.

\section{Primary Structure of DIssA}

In addition to mRNA 7 subgenomic RNA, DIssA may synthesize small amounts of other DIssA-specific subgenomic RNAs, and these putative DIssA-specific RNAs 
might be amplified by RT-PCR. Sequence analysis of cloned RT-PCR products of putative DIssA-specific subgenomic RNAs should reveal the primary structure of part of DIssA. MHV-specific cDNA was synthesized using oligonucleotide 1116. This oligonucleotide should hybridize with all MHV mRNAs and DIssA. The RT-PCR products were synthesized by incubating the cDNA with oligonucleotide 1116 and oligonucleotide 78. RT-PCR products were then examined by Southern blot analysis with a probe that specifically hybridizes to the $5^{\prime}$-region of gene 7 . We detected a $1.2 \mathrm{~kb}$-long RT-PCR product in JHM19th-infected cells, whereas we did not find this PCR product in all other samples, indicating that this RT-PCR product was synthesized from a DIssA-specific subgenomic RNA. We isolated this PR-PCR product and cloned it into a plasmid vector. We identified several clones by colony hybridization, and completely sequenced one $1.2 \mathrm{~kb}$-long clone, TA23 clone.

Sequence analysis revealed that structure of TA23 was similar to MHV-JHM mRNA $2-1$, but that it contained a large internal deletion spanning from nucleotide 876 in the transcription initiation site of gene 2-1 (or HE gene) to the $3^{\prime}$-region of gene 6 . The leader-body fusion site of TA23 was the same as MHV-JHM mRNA 2-1 ${ }^{2}$. This sequence analysis suggested that TA23 represented a cloned cDNA of a DIssA-specific subgenomic RNA. Because coronavirus mRNA forms a 3'-coterminal nested structure, the structure of TA23 indicated that DIssA lacks all of genes 3, 4, 5, most of gene 6 and the 3 '-one third of the HE gene.

We further confirmed the structure of DIssA by Northern blot analysis by using a probe corresponding to 362 - 670 nucleotides from the 5 '-transcription initiation site of the $\mathrm{HE}$ gene. With this probe, DIssA and three minor other RNAs, approximately $5.4 \mathrm{~kb}, 3.4 \mathrm{~kb}$ and $2.6 \mathrm{~kb}$ in length, were detected in the DIssA-replicating cells (data not shown). According to the size of RNAs, these three additional RNAs most probably represented the DIssA-specific subgenomic RNAs. The size of TA23 indicated that it most likely derived from the smallest $2.6 \mathrm{~kb}$ RNA. Based on the sizes of the other two RNAs, the $3.4 \mathrm{~kb}$ RNA probably had the same structure as MHV-JHM mRNA 2, which includes a large internal deletion like that of TA23; probably the largest $5.4 \mathrm{~kb}$ RNA, with the same deletion, started about $2 \mathrm{~kb}$ from the 3 '-region of DIssA gene 1. This Northern blot analysis demonstrated that DIssA synthesized three minor RNA species, in addition to mRNA 7.

\section{Gene Products from DIssA-related RNAs Supported Replication and Transcription of Another DI RNA}

Our data indicated that the gene 1 products, ns2 protein, part of the HE protein, and the $\mathrm{N}$ protein were expressed in the DIssA-replicating cells and that their expression was sufficient for replication and transcription of these DIssA-related RNAs. Would these gene products support replication and transcription of another DI RNA? We next examined whether these gene products supported RNA synthesis of other MHV RNA molecules in trans. MHV DIssF-derived MHV DI cDNA clone, MT 1/24 was used to examine this possibility. MT 1/24 DI RNA contains an inserted intergenic region preceding gene 7 and a subgenomic DI RNA is synthesized in MT 1/24-replicating, MHV-infected cells ${ }^{16}$. MT1/24 DI RNA was transfected into monolayers of DBT cells infected with LA16 $1 \mathrm{hr}$ prior to transfection ${ }^{16}$. After incubation of virus-infected cells at $32.5^{\circ} \mathrm{C}$ for $16 \mathrm{~h}, \mathrm{P} 0$ virus sample was obtained and further passaged to generate P1 virus sample. DBT cells were coinfected with this P1 virus sample and DIssA containing LA16 virus sample and cultured at nonpermissive temperature. Intracellular RNA was extracted from virus-infected cells and examined by Northern blot analysis (Fig. 2). Replication of MT 1/24 genomic DI RNA and transcription of MT 1/24 subgenomic DI RNA were observed in coinfected cells, demon- 
Figure 2. Northern blot analysis of intracellular RNA species. DBT cells were coinfected with two virus samples, P2 virus sample from LA 16 and JHM19th coinfected cells and P1 virus sample from MT 1/24-transfected, LA 16-infected cells, and cultured at $32.5^{\circ} \mathrm{C}$ (lanes 1 and 5) and $39.5^{\circ} \mathrm{C}$ (lanes $2-4$ and 6). Intracellular RNA was extracted, and $1.5 \mu \mathrm{g}$ of cytoplasmic RNA was separated on $1 \%$ formaldehyde-agarose gels and transferred to nylon filters. MHV RNA species were detected using a probe corresponding to the 3 '-end of genomic RNA. An arrowhead and an arrow represent MT 1/24 genomic DI RNA and subgenomic DI RNA, respectively. Lanes 1-4 were exposed for the same length of time. Lanes 5 and 6 are shorter exposure of lanes 1 and 2 .

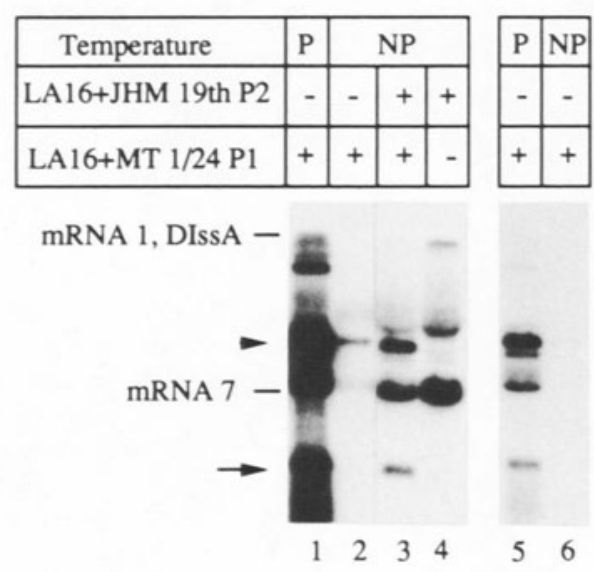

strating that gene 1 products and N protein supported RNA synthesis of other MHV RNA molecules in trans.

The ns2 protein and the HE protein are not necessary for MHV replication ${ }^{1,2}$. Although DIssA-specific subgenomic RNA appeared to encode the ns2 protein and part of the HE protein, the $3.4 \mathrm{~kb}$ and $2.6 \mathrm{~kb}$ RNAs are most probably not necessary for synthesis of DIssA RNA and its related RNAs or for MT 1/24 DI RNA. We concluded that expression of gene 1 products and N protein was sufficient for MHV RNA replication and transcription.

\section{DISCUSSION}

The present study and an in vitro MHV RNA replication study ${ }^{8}$ suggested that the $\mathrm{N}$ protein is necessary for MHV RNA synthesis. Coronavirus nucleocapsid is not required for initiation of coronavirus RNA synthesis, because coronavirus genomic RNA extracted from purified virions is infectious ${ }^{17,18}$. Possibly a subsequent step in coronavirus RNA synthesis, e.g., genomic RNA replication, may require a nucleocapsid template. How coronavirus $\mathrm{N}$ protein functions in coronavirus RNA synthesis is fundamental for the understanding of coronavirus RNA synthesis.

We found that the molar ratios of mRNA 1 to mRNA 7 in the helper virus-infected cells, and of DIssA and DIssA-derived mRNA 7 in the DIssA-replicating cells were both basically the same (Fig. 1). Also no significant difference was found between the molar ratios of MT 1/24 genomic RNA to subgenomic RNA in LA 16-infected cells and in DIssA-replicating cells (Fig. 2). These data indicated that MHV transcription efficiency was not altered by the expression of the MHV S protein, ns 4 protein, ns 5 a protein, ns $5 b$ protein, or M protein. This situation is different from influenza virus and vesicular stomatitis virus. In these viruses $M$ protein inhibits viral RNA transcription in vitro ${ }^{19,20}$.

\section{ACKNOWLEDGMENTS}

We thank Michael Lai and Stephen Stohlman for LA 16. We thank John Repass and Gwen Giles for excellent technical help. This work was supported by Public Health Service grants AI29984 and AI32591 from the National Institutes of Health. 


\section{REFERENCES}

1 Schwartz, B, Routledge, E, and Siddell, S G Murıne coronavirus nonstructural protein ns2 is not essential for viral replication in transformed cells J Virol 1990,64 4784-4791

2 Shieh, C -K, Lee, H J , Yokomorı, K, La Monıca, N, Makıno, S, and La1, M M C Identification of a new transcriptional initiation site and the corresponding functional gene $2 \mathrm{~b}$ in the murine coronavirus RNA genome J Virol 1989,63 3729-3736

3 Yokomorı, $\mathrm{K}$, and Laı, M M C Mouse hepatıtıs virus S sequence reveals that nonstructural proteins ns 4 and ns5a are not essential for murıne coronavirus replication J Virol 1991,65 5605-5608

4 Lee, H -J , Shieh, C -K , Gorbalenya,A E , Eugene, E V, La Monica, N, Tuler, J , Bagdzhadzhyan, A, and La1, M M C The complete sequence ( 22 kılobases) of murıne coronavirus gene 1 encoding the putatıve proteases and RNA polymerase Vırology 1991,180 567-582

5 Dveksler, G S , Pensiero, M N, Cardellıcjı, C B , Willıams, R K, Jiang, G -S Holmes, K V, and Dieffenbach, $\mathrm{C}$ W Cloning of the mouse hepatitis virus (MHV) receptor expression in human and hamster cell lines confers susceptibility to MHV J Virol 1991,65 6881-6891

6 Collıns, A R, Knobler, R L, Powell, H, and Buchmeıer, M J Monoclonal antıbodıes to murıne hepatıtıs virus-4 (strain JHM) define the viral glycoprotein responsible for attachment and cell fusion Virology 1982,119 358- 371

$7 \mathrm{Yu}, \mathrm{X}, \mathrm{B}$, W, Weiss, S R, and Leibowitz, J L Mouse hepatitis virus gene $5 \mathrm{~b}$ protein is a new virion envelope protein Virology 1994,202 1018-1023

8 Compton, S R, Rogers, D B, Holmes, K V, Fertsch, D, Remenıck, J, and McGowan, J J In vitro replication of mouse hepatitis virus strain A59 J Virol 1987,61 1814-1820

9 Makıno, S, Fujıoka, N, and Fujıwara, K Structure of the intracellular defectıve vıral RNAs of defectıve interfering particles of mouse hepatitıs virus J Virol 1985,54 329-336

10 Makıno, S, Shıeh, C-K, Keck, J G, and La1, M M C Defectıve-ınterferıng partıcles of murıne coronavirus mechanism of synthesis of defectıve viral RNAs Virology 1988,163 104-111

11 Makıno, S, Taguchı, F, and Fuııwara, K Defectıve interferıng partıcles of mouse hepatıtıs virus Vırology 1984,133 9-17

12 Barıc, R S, Fu, K, Schaad, M C and Stohlman, S A Establishing a genetic recombination map for murıne coronavirus strain A59 complementation groups Virology 1990,177 646-656

13 Makıno, S, Taguchı, F, Hırano, N , and Fujıwara, K Analysıs of genomıc and intracellular viral RNAs of small plaque mutants of mouse hepatitıs virus, JHM strain Vırology 1984,139 138-151

14 Jeong Y S , and Makıno, S Mechanısm of coronavirus transcription duration of primary transcription initiation activity and effect of subgenomic RNA transcription on RNA replication J Virol 1992, 66 3339-3346

15 Makıno, S , Joo,M and Makıno, J K A system for study of coronavirus mRNA synthesıs a regulated, expressed subgenomic defectıve interfering RNA results from intergenic site insertion J Virol 1991,65 6031-6041

16 Makıno, S, and Joo, M Effect of intergenic consensus sequence flanking sequences on coronavirus transcription J Virol 1993,67 3304-3311

17 Lamniczi, B Biological properties of avian coronavirus RNA J Gen Virol 1977,36 531-533

18 Schochetman, G, Stevens, R H and Simpson, R W Presence of infectious polyadenylated RNA in the coronavirus avian infectious bronchitıs virus Vırology 1977,77 772-782

19 Caroll, A R, and Wagner, R R Role of the membrane (M) protein in endogenous inhibition of in vitro transcription by vesicular stomatitis virus J Virol 1979,29 134-142

20 Zvonarjev, A Y, and Ghendon, Y Z Influence of membrane (M) protein on influenza A virus transcriptase activity in vitro and its susceptibility to rimantadine J Virol 1980,33 583-586 